\title{
Baseline concentration and sources of trace elements in groundwater of Cross River State, Nigeria
}

\author{
Aniekan Edet, Aniediobong Ukpong, Therese Nganje \\ Department of Geology, University of Calabar, POB 3609 Unical Post Office, Calabar, Nigeria
}

Email address:

aniekanedet@yahoo.com (A. Edet), aniekanedet25@gmail.com (A. Edet)

To cite this article:

Aniekan Edet, Aniediobong Ukpong, Therese Nganje. Baseline Concentration and Sources of Trace Elements in Groundwater of Cross River State, Nigeria. International Journal of Environmental Monitoring and Analysis. Vol. 2, No. 1, 2014, pp. 1-13.

doi: $10.11648 /$ j.ijema.20140201.11

\begin{abstract}
Groundwater samples were collected from wells in Cross River State (Nigeria) and analysed for trace elements including $\mathrm{Ba}, \mathrm{Co}, \mathrm{Cr}, \mathrm{Cu}, \mathrm{Fe}, \mathrm{Li}, \mathrm{Mn}, \mathrm{Mo}, \mathrm{Ni}, \mathrm{Pb}, \mathrm{Rb}, \mathrm{Sr}$ and $\mathrm{Zn}$. The primary aim of the study was to determine the baseline concentrations of these metals, while the secondary aim was to assess the present level of pollution, as a basis for future impact of human and industrial activities on the groundwater quality. Multivariate statistical methods were applied to determine the relationships between the different trace elements and also infer their different sources. The results showed that the contents of $\mathrm{Ba}, \mathrm{Fe}$, and $\mathrm{Pb}$ in groundwater from some locations were higher than the World Health Organisation, WHO maximum admissible concentration (MAC) of $700 \mu \mathrm{g} / \mathrm{l}, 300 \mu \mathrm{g} / \mathrm{l}$ and $100 \mu \mathrm{g} / 1$ respectively. The contents of Cd, Co, $\mathrm{Cu}, \mathrm{Fe}, \mathrm{Mn}, \mathrm{Ni}, \mathrm{Pb}, \mathrm{Rb}$ and $\mathrm{Zn}$ were lower than the concentrations in freshwater, while the contents of $\mathrm{Ba}, \mathrm{Cr}, \mathrm{Li}, \mathrm{Mo}$ and $\mathrm{Sr}$ in some of the locations exceeded the values in typical freshwater. Correlation and cluster analyses indicated common sources for some elements, while factor analysis suggested dissolution of brine, dissolution of barite mineral, weathering of the bedrock and prevailing oxidation-reduction potential of the environment as the main factors responsible for the occurrence of these trace elements in groundwater. The present data therefore is expected to serve as a good guide for future groundwater management of the area.
\end{abstract}

Keywords: Trace Metals, Background Values, Multivariate Analysis, Pollution, Nigeria

\section{Introduction}

Groundwater can be polluted with trace elements from a variety of sources, such as weathering, decomposed vegetative and animal matter, fallout from air particulate and industrial activities [1]. Though some trace metals such as copper, cadmium, chromium, zinc etc are essential to humans, however when the concentration is high, it may cause some physiological disorder $[1,2]$. Therefore, there is the need to document the present levels of trace metals in groundwater, especially in an industrially virgin area such as the present study area. Few studies have been conducted with respect to the content of trace elements in water of the study area. For example, [3, 4] documented the distribution of Fe and $\mathrm{Mn}$ in surface waters of Akpabuyo and Odukpani in the southern parts of the study area. Reference [5], reported on the use of different indices for monitoring heavy metal contamination in southern parts of Cross River State. Analysis of groundwater from Calabar area in the south indicated that most trace elements in groundwater were below normal averages and do not pose any risk to the aquifer [6, 7]. References [8] and [9], noted that the concentrations of $\mathrm{Fe}$ and $\mathrm{Mn}$ in groundwater of northern parts of the Cross River State were within the normal averages when compared to global waters

A large number of workers have also researched on trace elements contents of groundwater in Nigeria. However, majority of these works were tailored to the contents of Fe and $\mathrm{Mn}$. Reference [10] revealed that the concentrations of $\mathrm{Fe}$ and $\mathrm{Mn}$ in groundwater of Nigeria are due to natural sources. They also reported that, the maximum values observed for $\mathrm{Fe}$ and $\mathrm{Mn}$ in groundwater of Nigeria were well over the WHO [11] guideline values of $0.30 \mathrm{mg} / \mathrm{l}$ and $0.10 \mathrm{mg} / \mathrm{l}$ for Fe and $\mathrm{Mn}$, respectively.

To date no baseline or comprehensive study has been done to determine the trace element content in the groundwater of the study area. In this study, therefore the concentration of various trace elements and their sources were carried out as a prelude to future industrial development and attendant pollution in the study area. 


\section{The Cross River State Area}

The study area, Cross River State is situated in southeastern corner of Nigeria (Fig. 1). The mean annual rainfall for the area varied from more than $3000 \mathrm{~mm}$ in the south through about $2000 \mathrm{~mm}$ in the central parts to less than $1800 \mathrm{~mm}$ in the north. The rainfall patterns consist of alternating wet (April-October) and dry (November-March) periods. Mean annual air temperature for the area ranged from $30.1^{\circ} \mathrm{C}$ in the north to $22.4^{\circ} \mathrm{C}$ in the south [12].

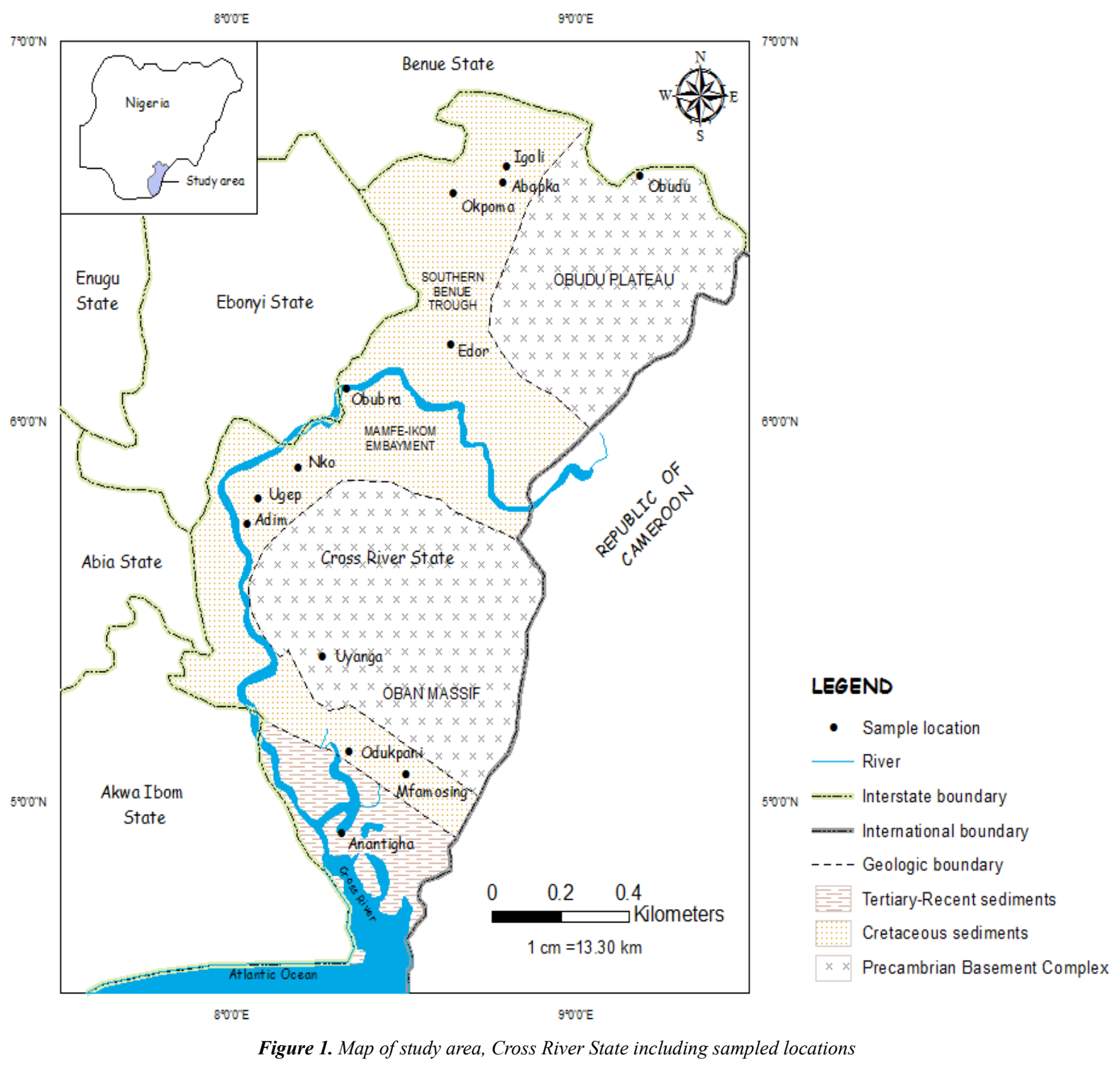

The main physical features of Cross River State include highlands with elevations in excess of $400 \mathrm{~m}$ above sea level. By contrast, the low lands have elevations of up to $350 \mathrm{~m}$ decreasing southwards to a few meters near the coast in the south. In terms of geology, the area is underlain by Precambrian Crystalline Basement. Cretaceous to Tertiary age sedimentary rocks overlies the basement rocks. The basement areas consist predominantly of gneisses, schists, amphibolites, pegmatites, granites, granodiorites, diorites, tonalities etc, while the sedimentary formations consists of conglomerates, sandstones, shale, limestones, marls, clays, sands and silts. The hydrogeology is largely dependent on the lithology of the area. The major hydrogeological units of the area are the crystalline basement; sandstonesiltstone-limestone-intrusive; shale-intrusive; shale; coastal plain sand and alluvium $[13,14]$.

\section{Materials and Methods}

\subsection{Sampling and Analyses}

Sixteen groundwater samples were collected from 13 locations within the study area (Figure 1). Sampling, preservation and analyses of the groundwater samples were based on standard procedures as described in Reference [15]. The groundwater temperature, $\mathrm{pH} / \mathrm{Eh}$, electrical conductivity (EC)/total dissolved solids (TDS) and dissolved oxygen (DO) were conducted insitu using potable kits. The analyses for trace elements were performed using a Parkin Elmer ELAN 6000 inductively coupled plasma 
mass spectrophotometer (ICP-MS) at the Institute of Agricultural Chemistry, University of Hohenhiem, Germany.

\subsection{Statistical Methods}

Conventional statistical analyses including mean, median, minimum, maximum, and standard deviation (SD) were conducted as a first step towards an understanding of the behaviour of the heavy metal data. Correlation analyses were used to construct the relationships between the different trace elements. Cluster analysis (CA), a measure of multivariate technique allowed objects to be assembled on the basis of its characteristics. CA classified objects so that each object was similar to the others in the cluster with respect to predetermined selection criterion. The hierarchical agglomerative clustering was the most common approach, which provided intuitive similarly relationships between any one sample and the entire data set and illustrated by a dendrogram. The dendrogram provided a visual summary of the clustering processes and presented a picture of groups with their proximity with drastic reduction in dimensionality of the original data $[16$, 17].

Factor analysis, which included principal component analysis (PCA), was applied to reduce dimensionality of data set that consisted of a large number of interrelated variables, and this reduction was achieved by transforming the data set into new set of variables. The principal components (PCs), which are orthogonal, were arranged in order of decreasing importance. The PCs were computed from covariance or other cross-products matrix, which described the dispersion of multiple measured parameters to obtain eigenvalues and eigenvectors. PCA is used to reduce the variable numbers and explained the same amount of variance with fewer variables [18]. Factor analysis attempted to explain the correlations between the observations interms of the underlying factors which are not directly observable (Yu et al., 2003). The statistical analyses were performed by means of the statistical package, STAISTICA [19]. In carrying out the statistical analysis, where a value of elemental concentration was less than the detectable limit, the value of detectable limit was used (e.g. $<0.1$ was used as 0.1).

\subsection{Speciation}

The computer program PHREEQC using the database wateq $4 \mathrm{f}$ was used to calculate the distribution of the aqueous species. The database includes the following elements: aluminium, arsenic, barium, boron, bromine, cadmium, calcium, carbon, cerium chlorine, copper, fluorine, hydrogen, iodine, iron, lead, lithium, magnesium, manganese, nickel, nitrogen, oxygen, phosphorus, potassium, silicon, sodium, strontium, sulphur, rubidium, selenium, silver and zinc [20]. The program is designed to perform a wide variety of aqueous geochemical calculations, based on an ion-association aqueous model.

\section{Results and Discussion}

The analytical results are listed in Table 1 and the statistical summary listed in Table 2 .

\subsection{Physicochemical Characteristics of the Groundwater}

The temperature of the groundwater samples ranged from 28.4 to $31.1^{\circ} \mathrm{C}$. The Electrical conductivity (EC) and Total Dissolved Solids (TDS) varied from a low of 70.8 to a high of $2416 \mu \mathrm{S} / \mathrm{cm}$ and from 35.4 to $1213 \mathrm{ppm}$. Three samples exceeded the World Health Organisation [11, 21, 22] maximum admissible value (MAV) of $1400 \mu \mathrm{S} / \mathrm{cm}(\mathrm{EC})$ and $1000 \mathrm{ppm}$ (TDS). The $\mathrm{pH}$ values ranged between 5.32 and 7.85 revealing acidic to alkaline groundwater. A

Table 1. Physicochemical parameters (A) and trace elements (B) contents in groundwater samples, Cross River State, Nigeria.

\begin{tabular}{|c|c|c|c|c|c|c|c|c|c|c|c|c|}
\hline Location Name ${ }^{a}$ & Temp & EC & TDS & pH & $\mathrm{Na}^{+}$ & $\mathbf{K}^{+}$ & $\mathrm{Ca}^{2+}$ & $\mathrm{Mg}^{2+}$ & $\mathrm{Cl}^{-}$ & $\mathrm{HCO}_{3}^{-}$ & $\mathrm{SO}_{4}{ }^{2-}$ & $\mathrm{NO}_{3}^{-}$ \\
\hline & ${ }^{\circ} \mathrm{C}$ & $\mu \mathrm{S} / \mathrm{cm}$ & ppm & & & & & $\mathrm{mg} / \mathrm{L}$ & & & & \\
\hline Anantigha & 28.70 & 209.70 & 104.90 & 5.32 & 34.73 & 1.88 & 4.47 & 0.47 & 27.39 & 21.50 & 0.38 & 51.62 \\
\hline Odukpani & 28.40 & 178.20 & 89.10 & 6.39 & 7.68 & 4.21 & 19.92 & 1.41 & 7.84 & 17.80 & 7.03 & 33.34 \\
\hline Uyanga & 28.70 & 101.90 & 51.00 & 6.16 & 5.64 & 2.07 & 11.48 & 1.18 & 4.92 & 10.30 & 2.63 & 9.82 \\
\hline Adim & 29.80 & 88.00 & 44.10 & 6.08 & 3.08 & 2.16 & 11.41 & 0.54 & 0.98 & 8.10 & 2.01 & 0.07 \\
\hline Ugep & 29.30 & 98.90 & 49.40 & 5.68 & 9.76 & 4.64 & 5.33 & 0.38 & 7.75 & 10.10 & 4.69 & 14.79 \\
\hline Obubra & 29.20 & 95.50 & 47.70 & 5.86 & 5.78 & 1.28 & 4.76 & 1.79 & 7.09 & 6.91 & nd & 5.41 \\
\hline Okpoma & 28.80 & 70.80 & 35.40 & 5.94 & 5.78 & 1.28 & 4.76 & 1.79 & 7.09 & 6.91 & nd & 5.41 \\
\hline Igoli & 29.60 & 2416.00 & 1213.00 & 7.61 & 676.27 & 10.28 & 8.98 & 6.34 & 11.86 & 80.00 & 626.05 & 4.97 \\
\hline Abakpa & 29.90 & 773.00 & 387.00 & 5.35 & 89.68 & 45.40 & 32.19 & 7.00 & 139.02 & 40.00 & 2.10 & 187.04 \\
\hline Edor & 30.10 & 94.60 & 47.30 & 5.86 & 13.55 & 3.40 & 4.20 & 0.70 & 7.77 & 9.75 & nd & 25.48 \\
\hline Nko & 28.80 & 944.00 & 465.00 & 7.85 & 65.09 & 108.93 & 68.79 & 8.74 & 99.63 & 60.00 & 55.33 & 51.08 \\
\hline Obudu & 29.00 & 70.80 & 35.40 & 6.25 & 2.88 & 0.64 & 11.47 & 0.38 & 2.30 & 7.90 & 0.46 & 3.45 \\
\hline Mbarakom & & & & & & & & & & & & \\
\hline
\end{tabular}


B

\begin{tabular}{lllllllllllllll}
\hline $\begin{array}{l}\text { Location } \\
\text { Name }\end{array}$ & Ba & $\mathbf{C d}$ & $\mathbf{C o}$ & $\mathbf{C r}$ & $\mathbf{C u}$ & $\mathbf{F e}$ & $\mathbf{L i}$ & $\mathbf{M n}$ & $\mathbf{M o}$ & $\mathbf{N i}$ & $\mathbf{P b}$ & $\mathbf{R b}$ & $\mathbf{S r}$ & $\mathbf{Z n}$ \\
\hline & & & & & & & & $\mu \mathrm{g} / \mathrm{L}$ & & & & & \\
Anantigha & 71 & $<0.10$ & 0.41 & 2.0 & 1.2 & $<1.0$ & $<1$ & 36 & $<0.10$ & 1.0 & 10 & 7.2 & 21 & 12 \\
Odukpani & 28 & $<0.10$ & $<0.10$ & 4.6 & 0.25 & $<1.0$ & $<1$ & $<1.0$ & 1.8 & $<1.0$ & $<0.10$ & 19 & 96 & 5.0 \\
Uyanga & 42 & $<0.10$ & 0.40 & 4.4 & 0.23 & $<1.0$ & 1.5 & 15 & 0.40 & $<1.0$ & 1.4 & 3.7 & 27 & 3.0 \\
Adim & 94 & $<0.10$ & 0.34 & 3.3 & 0.79 & 1600 & $<1$ & 3.4 & 0.57 & 1.2 & 1.5 & 8.1 & 55 & 4.1 \\
Ugep & 106 & $<0.10$ & 0.12 & $<1.0$ & 0.13 & $<1.0$ & $<1$ & 15 & $<0.10$ & $<1.0$ & $<0.10$ & 10 & 31 & 9.0 \\
Obubra & 46 & $<0.10$ & 0.11 & 3.8 & 0.30 & 320 & $<1$ & 1.7 & $<0.10$ & $<1.0$ & 2.9 & 3.3 & 49 & 1.5 \\
Okpoma & 78 & $<0.10$ & $<0.10$ & 6.5 & 0.18 & $<1.0$ & 7.2 & $<1.0$ & 0.16 & $<1.0$ & $<0.10$ & 1.1 & 608 & $<0.10$ \\
Igoli & 48 & $<0.10$ & $<0.10$ & 26 & 4.3 & $<1.0$ & 83 & 37 & 0.40 & $<1.0$ & $<0.10$ & 4.3 & 1180 & 152 \\
Abakpa & 802 & $<0.10$ & 5.5 & 3.4 & 2.8 & $<1.0$ & 4.7 & 207 & $<0.10$ & 6.7 & 13 & 53 & 284 \\
Edor & 111 & $<0.10$ & $<0.10$ & $<1.0$ & $<0.10$ & $<1.0$ & $<1$ & $<1.0$ & $<0.10$ & $<1.0$ & $<0.10$ & 8.7 & 22 & 3.4 \\
Nko & 176 & $<0.10$ & 0.59 & 7.1 & 1.5 & $<1.0$ & $<1$ & $<1.0$ & 1.9 & $<1.0$ & $<0.10$ & 109 & 399 & 12 \\
Obudu & 89 & $<0.10$ & $<0.10$ & 2.9 & 0.40 & 89 & $<1$ & $<1.0$ & 0.47 & 1.2 & $<0.10$ & 19 & 58 & $<0.10$ \\
Mbarakom & 812 & $<0.10$ & $<0.10$ & $<1.0$ & 0.27 & $<1.0$ & 2.4 & 2.3 & $<0.10$ & $<1.0$ & $<0.10$ & 34 & 110 & 1.7 \\
\hline
\end{tabular}

${ }^{\mathrm{a}}$ See Fig. 1

The chloride values ranged between 0.98 and $139.02 \mathrm{mg} / 1$ with an average of $26.97 \mathrm{mg} / \mathrm{l}$. The nitrate contents ranged from 0.07 to $187.04 \mathrm{mg} / \mathrm{l}$ with an average of $32.7 \mathrm{mg} / \mathrm{l}$. Three samples from Anantigha, Nko and Abakpa exceeded the MAV of $10 \mathrm{mg} / \mathrm{l}$. Sulphate contents ranged from 0.38 to $626.05 \mathrm{mg} / \mathrm{l}$ with average of $58.93 \mathrm{mg} / 1$ with one sample from Igoli exceeding the MAV of $400 \mathrm{mg} / \mathrm{l}$. The concentration of bicarbonate varied between 6.91 and 80.0 $\mathrm{mg} / \mathrm{l}$ with an average of $23.27 \mathrm{mg} / \mathrm{l}$.

The sodium contents ranged from 2.88 to $676.27 \mathrm{mg} / \mathrm{l}$ (average of $76.66 \mathrm{mg} / \mathrm{l}$ ) with one sample $(10 \%)$ exceeding the MAV of $200 \mathrm{mg} / 1$ and 11 samples $(90 \%)$ have concentrations lower than the MAV. The potassium values ranged from 0.64 to $108.93 \mathrm{mg} / 1$ with an average of 15.51 $\mathrm{mg} / \mathrm{l}$ with two samples from Abakpa $(45.4 \mathrm{mg} / \mathrm{l})$ and Nko (108.93 mg/l) exceeding the MAV of $12 \mathrm{mg} / \mathrm{l}$. The calcium contents varied from 4.2 to $68.79 \mathrm{mg} / 1$ (average of 15.65 $\mathrm{mg} / \mathrm{l})$. The contents of magnesium ranged from 0.38 to 8.74 $\mathrm{mg} / \mathrm{l}$ (average $2.56 \mathrm{mg} / \mathrm{l}$ ).

\subsection{Concentration of Trace Metal in Groundwater}

\section{Barium (Ba)}

The average content of barium in the groundwateris $192.54 \mu \mathrm{g} / \mathrm{l}$. The Ba concentration in two samples exceeded the MAV $(700 \mu \mathrm{g} / \mathrm{l})$. However, the contents of $\mathrm{Ba}$ in all the groundwater samples exceeded typical value in freshwater of $3 \mu \mathrm{g} / 1$ [27]. More than $75 \%$ of barium contents in groundwater are in the ionic form $\mathrm{Ba}^{2+}$. The relatively high concentration of barium was attributed to barite mineralization in the study area $[23,24,25,26]$.

\section{Cadmium (Cd)}

$\mathrm{Cd}$ contents in the groundwater of the study area were below the detection limit (BDL) of the equipment $(<$
$0.10 \mu \mathrm{g} / \mathrm{l})$ from all the locations within the study area. This was attributed to low cadmium related activity and /or nongeologic source.

\section{Cobolt (Co)}

The contents of Co in six samples were BDL. All the samples had Co concentrations below the values for typical freshwater $(10-18 \mu \mathrm{g} / \mathrm{l})$, [27]. Co is non-toxic and more than $70 \%$ occurred in the ionic form as $\mathrm{Co}(\mathrm{OH})_{2}$, while less than $10 \%$ occurred in the form $\mathrm{Co}^{2+}$.

\section{Chromium (Cr)}

Chromium is a low mobility element especially, under moderately oxidizing and reducing conditions and near neutral $\mathrm{pH}$ (Machender et al., 2011). Cr values ranged between $<0.10$ and $26.0 \mu \mathrm{g} / \mathrm{l}$ with three samples having concentrations BDL. The concentrations of $\mathrm{Cr}$ in 10 samples were lower than the MAV $(50 \mu \mathrm{g} / \mathrm{L})$, but higher than typical value in freshwater of $0.18 \mu \mathrm{g} / 1$ [27]. $\mathrm{Cr}$ occurred in the ionic form, $\mathrm{CrOH}^{+}$in groundwater of the study area.

\section{Copper (Cu)}

The contents of $\mathrm{Cu}$ in all samples considered were lower than the MAV of $1000 \mu \mathrm{g} / 1$ and typical values in freshwater $(10-2800 \mu \mathrm{g} / \mathrm{L})$. The ionic form, $\mathrm{Cu}(\mathrm{OH})_{2}$ was the main species, which constituted more than $60 \%$ of the total copper in groundwater of Cross River State.

\section{Iron $(\mathrm{Fe})$}

Eighty five per cent of the groundwater samples complied with the MAV $(300 \mu \mathrm{g} / \mathrm{l})$ for drinking and domestic purposes in terms of $\mathrm{Fe}$ content. Samples from two locations at Obubra and Adim exceeded the MAV.. However, the content of $\mathrm{Fe}$ in all the groundwater samples 
fell within the range documented for freshwater (0.04 $6200 \mu \mathrm{g} / \mathrm{l})$.

High iron concentration in groundwater in some locations probably resulted from interaction of oxidized iron minerals and organic matter and subsequent dissolution of $\mathrm{Fe}_{2} \mathrm{CO}_{3}$ at a comparatively lower $\mathrm{pH}$ [2]. Another probable source of the high iron content was attributed to the removal of dissolved oxygen by organic matter, which resulted in reduced conditions. Under reducing conditions, the solubility of iron bearing minerals increases leading to enrichment of dissolved iron content in groundwater [28, 29].

\section{Lithium (Li)}

The content of $\mathrm{Li}$ in the groundwater of the study area were below the MAV of $50 \mu \mathrm{g} / 1$. One sample (Igoli), however had $\mathrm{Li}$ content of $83 \mu \mathrm{g} / \mathrm{l}$. The concentrations of $\mathrm{Li}$ in groundwater samples from four locations (Igoli, Abakpa, Uyanga, Mbarakom) exceeded typical $\mathrm{Li}$ content in freshwater $(1.1 \mu \mathrm{g} / \mathrm{l})$. The relatively high contents of lithium at Igoli and Abakpa were related to the saline groundwater in these locations.

\section{Manganese (Mn)}

The average value is $24.8 \mu \mathrm{g} / \mathrm{L}$, which is lower than the MAV $(500 \mu \mathrm{g} / \mathrm{l})$ and within the average range in freshwater $(0.1-110 \mu \mathrm{g} / \mathrm{L})$.

\section{Molybdenum (Mo)}

Molybdenum contents were below the MAV of $70 \mu \mathrm{g} / 1$. The concentrations in groundwater from five locations (Odukpani, Adim, Nko, Uyanga, Obudu) exceeded typical level in freshwater of $0.3 \mu \mathrm{g} / \mathrm{L}$. The dominant dissolved molybdenum species in the groundwater of the study area is $\mathrm{MoO}_{4}$ comprising between 73.6 and $96.6 \%$ in groundwater of the area.

\section{Nickel (Ni)}

The values of $\mathrm{Ni}$ are below the MAV of $70 \mu \mathrm{g} / \mathrm{L}$. In all the locations sampled, the concentrations of $\mathrm{Ni}$ were lower than the level of $\mathrm{Ni}$ in a typical freshwater $(10 \mu \mathrm{g} / \mathrm{l})$. The dominant species of nickel in the groundwater include $\mathrm{Ni}$ $(\mathrm{OH})_{2}$ comprising 45 to $63 \% ; \mathrm{Ni}^{2+}$ with 11 to $20 \% ; \mathrm{NiCO}_{3}$, 10 to $17 \%$ and $\mathrm{Ni}(\mathrm{OH})^{+} .10$ to $16 \%$.

\section{Lead $(P b)$}

More than $90 \%$ of the groundwater samples had $\mathrm{Pb}$ values below the MAV of $10 \mu \mathrm{g} / \mathrm{L}$ and typical values in freshwater of $10-5600 \mu \mathrm{g} / \mathrm{l}$. The dominant lead species in groundwater of the study area include $\mathrm{Pb}(\mathrm{OH})_{2}$ comprising $15-55 \%$ and $\mathrm{Pb}\left(\mathrm{CO}_{3}\right)_{2}$ varying between 10 and $55 \%$. The other lead species in the groundwater were $\mathrm{Pb}(\mathrm{OH}), \mathrm{PbCO}_{3}$ and $\mathrm{Pb}$ $(\mathrm{OH})_{3}$ respectively, in the range $12-33 \%, 12-16 \%$ and $10-$ $16 \%$.

\section{Rubidium (Rb)}

The concentration of $\mathrm{Rb}$ exceeded concentration in typical freshwater $(1.0 \mu \mathrm{g} / \mathrm{L})$.

\section{Strontium (Sr)}

The concentrations of $\mathrm{Sr}$ in groundwater of the study area exceeded typical concentration in freshwater $(50.0 \mu \mathrm{g} / \mathrm{l})$ at seven locations. The main source of strontium is attributable to the saline groundwater at Abakpa, Igoli, Nko and Okpoma [30, 31, 32, 33].

\section{Zinc (Zn)}

The concentrations of zinc in groundwater of the area are lower than the MAV of $5000 \mu \mathrm{g} / \mathrm{l}$ and average concentration in typical freshwater $(0.1-240 \mu \mathrm{g} / \mathrm{L})$. In all the groundwater samples considered, $\mathrm{Zn}(\mathrm{OH})$ constituted the major ionic species ranging between $91.5 \%$ and $96.0 \%$.

Table 2. Statistical summary of physicochemical parameters and trace elements contents in groundwater samples, Cross River State, Nigeria.

\begin{tabular}{|c|c|c|c|c|c|c|c|c|c|c|c|}
\hline Type & Parameter & Units & Mean & Med & Min & $\operatorname{Max}$ & $\mathrm{SD}$ & $\mathrm{MAV}^{\mathrm{a}}$ & Freshwater $^{\mathrm{b}}$ & $\begin{array}{l}\text { Background } \\
\text { value }^{c}\end{array}$ & $\begin{array}{l}\text { Threshold } \\
\text { value }^{\mathrm{c}}\end{array}$ \\
\hline \multirow{5}{*}{ Physical } & Temp & ${ }^{\circ} \mathrm{C}$ & 29.19 & 29.00 & 28.40 & 30.10 & 0.58 & & & & \\
\hline & TDS & ppm & 229.24 & 51.00 & 35.40 & 1213.00 & 359.16 & 1000 & & & \\
\hline & $\mathrm{pH}$ & & 6.20 & 6.01 & 5.32 & 7.85 & 0.79 & $6.5-8.5$ & & & \\
\hline & $\mathrm{K}^{+}$ & & 15.51 & 2.78 & 0.64 & 108.93 & 31.93 & 12 & & & \\
\hline & $\mathrm{Ca}^{2+}$ & & 15.65 & 10.20 & 4.20 & 68.79 & 18.62 & & & & \\
\hline \multirow[t]{7}{*}{ Chemical } & $\mathrm{Mg}^{2+}$ & $\mathrm{mg} / \mathrm{l}$ & 2.56 & 1.30 & 0.38 & 8.74 & 2.99 & 100 & & & \\
\hline & $\mathrm{Cl}^{-}$ & & 26.97 & 7.76 & 0.98 & 139.02 & 44.44 & 250 & & & \\
\hline & $\mathrm{HCO}_{3}^{-}$ & & 23.27 & 10.20 & 6.91 & 80.00 & 24.13 & & & & \\
\hline & $\mathrm{NO}_{3}^{-}$ & & 32.71 & 12.30 & 0.07 & 187.04 & 51.87 & 50 & & & \\
\hline & $\mathrm{Ba}$ & & 192.54 & 89.00 & 28.00 & 812.00 & 275.38 & 700 & 3 & 800 & 800.00 \\
\hline & $\mathrm{Cd}$ & & 0.10 & 0.10 & 0.10 & 0.10 & 0.00 & 5 & 0 & 0.1 & 0.10 \\
\hline & Co & & 0.62 & 0.11 & 0.10 & 5.50 & 1.48 & $1000^{d}$ & $10.0-18.0$ & 0.43 & 0.47 \\
\hline
\end{tabular}




\begin{tabular}{|c|c|c|c|c|c|c|c|c|c|c|c|}
\hline Type & Parameter & Units & Mean & Med & Min & $\operatorname{Max}$ & SD & $\mathrm{MAV}^{\mathrm{a}}$ & Freshwater $^{b}$ & $\begin{array}{l}\text { Background } \\
\text { value }^{\mathrm{c}}\end{array}$ & $\begin{array}{l}\text { Threshold } \\
\text { value }^{\mathrm{c}}\end{array}$ \\
\hline \multirow{11}{*}{$\begin{array}{l}\text { Heavy } \\
\text { metal }\end{array}$} & $\mathrm{Cr}$ & \multirow{11}{*}{$\mu \mathrm{g} / 1$} & 5.15 & 3.40 & 1.00 & 26.00 & 6.56 & 50 & 0.18 & 4.2 & 4.20 \\
\hline & $\mathrm{Cu}$ & & 0.96 & 0.30 & 0.10 & 4.30 & 1.27 & 1000 & $10.0-2800.0$ & 0.44 & 1.72 \\
\hline & $\mathrm{Fe}$ & & 155.31 & 1.00 & 1.00 & 1600.00 & 443.17 & 300 & $40.0-6200000$ & 4.1 & 4.10 \\
\hline & $\mathrm{Li}$ & & 8.22 & 1.00 & 1.00 & 83.00 & 22.55 & 50 & 1.1 & 4.2 & 4.60 \\
\hline & $\mathrm{Mn}$ & & 24.80 & 2.30 & 1.00 & 207.00 & 56.27 & 50 & $100.0-110000.0$ & 0.43 & 0.72 \\
\hline & Mo & & 0.48 & 0.16 & 0.10 & 1.90 & 0.63 & 70 & 0.3 & 3.5 & 3.50 \\
\hline & $\mathrm{Ni}$ & & 1.47 & 1.00 & 1.00 & 6.70 & 1.57 & 70 & 10 & 0.43 & 1.72 \\
\hline & $\mathrm{Pb}$ & & 2.28 & 0.10 & 0.10 & 13.00 & 4.23 & 100 & $10.0-5600.0$ & 4.4 & 4.40 \\
\hline & $\mathrm{Rb}$ & & 21.57 & 8.70 & 1.10 & 109.00 & 30.08 & & 1 & 43 & 46.50 \\
\hline & $\mathrm{Sr}$ & & 226.15 & 58.00 & 21.00 & 1180.00 & 337.85 & & 50 & 4.3 & 4.65 \\
\hline & $\mathrm{Zn}$ & & 16.92 & 4.10 & 0.10 & 152.00 & 40.90 & 5000 & $0.1-240$ & 3.5 & 3.50 \\
\hline
\end{tabular}

${ }^{\mathrm{a}}$ WHO (1993, 2004, 2008); ${ }^{\mathrm{b}}$ Pais and Jones Jr; ${ }^{\mathrm{c} C o e s t s i e r s ~ e t ~ a l ., ~ 2009 ; ~}{ }^{\mathrm{d}}$ Siegel, 2002(MAV-Maximum Admissible Value;Med-Median; Min-Minimum; MaxMaximum; SD-Standard Deviation; MCL-maximum Admissible value; RV-Reference value)

\subsection{Trace Elements and Lithology}

The range of contents of different elements in groundwater samples within different lithologic units are presented in table 3 . The data showed that the highest concentrations were obtained from the sandstone terrain, while the lowest concentrations were from the basement, which consist of igneous and metamorphic rocks. The low concentrations were attributed to the fact that, when the basement rocks are weathered, the weathered materials tend to be transported to sedimentary terrain in the lower elevations along with the dissolved elements. The high concentrations in the sandstone were attributed to the salt deposits associated with them [30, 31, 32, 33].

\subsection{Natural Background Level (NBL) and Threshold Values (TV)}

Natural background levels (NBL) and threshold values (TV) for the trace metals were established following the method of reference [34]. For the determination of NBL, the method utilized a value defined as the 90 or 97.7 percentile of a chosen dataset to approach the natural composition of the media when no national method exist for derivation of NBL. The selection of 90 or 97.9 percentile depends on the amount of data. When large amount of data ( $\geq 60$ sampling points) are available, the 97.7 percentile is preferred; while for smaller data set $(<60$ sampling points), the 90 percentile is suggested. The sample points in the present study were less than 60 , hence the 90 percentile was applied. For the determination of threshold values (TV), two cases were suggested as follows [34]:

Case $1: \mathrm{NBL}<\mathrm{REF}: \mathrm{TV}=(\mathrm{NBL}+\mathrm{REF}) / 2$

Case $2: \mathrm{NBL} \geq \mathrm{REF}: \mathrm{TV}=\mathrm{NBL}$

where REF is the baseline concentration in natural or unpolluted groundwater or guideline or maximum admissible concentration. The natural background level and threshold values for the trace metals are presented in Table 2 .

Table 3. Classification of metals in groundwater samples from different geologic terrain

\begin{tabular}{|c|c|c|c|c|}
\hline Element & Sand & Shale & Sandstone & Basement \\
\hline $\mathrm{Ba}$ & 71 & $28-78$ & $48-802$ & $42-812$ \\
\hline $\mathrm{Cd}$ & $<0.10$ & $<0.10$ & $<0.10$ & $<0.10$ \\
\hline $\mathrm{Co}$ & 0.41 & $<0.10-0.11$ & $<0.10-5.5$ & $<0.10-0.10$ \\
\hline $\mathrm{Cr}$ & 2.0 & $3.8-6.5$ & $<1.00-26.0$ & $<1.00-4.4$ \\
\hline $\mathrm{Cu}$ & 1.2 & $0.18-0.30$ & $<0.10-4.3$ & $0.23-0.40$ \\
\hline $\mathrm{Fe}$ & $<1.0$ & $<1.00-320$ & $<1.00-1600$ & $<1.00-89.0$ \\
\hline $\mathrm{Li}$ & $<1.0$ & $<1.00-7.2$ & $<1.00-83.0$ & $<1.00-2.4$ \\
\hline Mn & 36 & $<1.00-1.7$ & $<1.00-207$ & $<1.00-15.0$ \\
\hline Mo & $<0.10$ & $<0.10-1.8$ & $<0.10-1.9$ & $<0.10-0.47$ \\
\hline $\mathrm{Ni}$ & 1.0 & $<1.0$ & $<1.00-6.7$ & $<1.00-1.2$ \\
\hline $\mathrm{Pb}$ & 10 & $<0.10-2.9$ & $<0.10-13.0$ & $<0.10-1.4$ \\
\hline $\mathrm{Rb}$ & 7.2 & $1.10-3.30$ & $4.30-109$ & $3.7-34.0$ \\
\hline $\mathrm{Sr}$ & 21 & $49-608$ & $22-1180$ & $27-110$ \\
\hline $\mathrm{Zn}$ & 12 & $<0.10-5.0$ & $3.40-152$ & $<0.10-3.0$ \\
\hline
\end{tabular}


Table 4. Classification of groundwater samples from Cross River State based on metal load

\begin{tabular}{llll}
\hline Metal Load & $\mathbf{p H}$ & Classification & Studied sample \\
\hline $\mathbf{m g} / \mathbf{l}$ & & & \\
$<1$ & & High acid Low metal & \\
$1-100$ & $<3$ & $\begin{array}{l}\text { High acid High metal } \\
\text { High acid Extreme metal }\end{array}$ \\
$>100$ & & Acid Low metal \\
$<1$ & & Acid High metal & \\
$1-100$ & $3 .-5$ & Acid Extreme metal & \\
$>100$ & & Near Neutral Low metal & Anantigha, Edor, Mbarakom, Nko, Obubra, Obudu, Odukpani, Okpoma, Ugep, Uyanga \\
$<1$ & & Near Neutral High metal & Abakpa, Adim, Igoli \\
$1-100$ & $>5$ & Near Neutral Extreme metal & \\
\hline 100 & &
\end{tabular}

Table 5. Calculated index of geo-accumulation (I-geo)

\begin{tabular}{|c|c|c|c|c|c|c|c|c|c|c|c|c|c|c|c|c|}
\hline $\mathbf{S} / \mathbf{N}$ & Sample ID & Location name & $\mathbf{B a}$ & Cd & Co & $\mathrm{Cr}$ & $\mathrm{Cu}$ & $\mathrm{Fe}$ & $\mathbf{L i}$ & Mn & Mo & $\mathbf{N i}$ & $\mathbf{P b}$ & $\mathbf{R b}$ & $\mathrm{Sr}$ & $\mathbf{Z n}$ \\
\hline 1 & CR 12 & Anantigha & -4.08 & -0.58 & -0.65 & -1.66 & 0.86 & -2.62 & -2.66 & 5.80 & -5.71 & 0.63 & 0.60 & -3.16 & 1.70 & 1.19 \\
\hline 2 & CR 13 & $\begin{array}{l}\text { Odukpani Qua } \\
\text { Town }\end{array}$ & -5.42 & -0.58 & -2.69 & -0.45 & -1.40 & -2.62 & -2.66 & 0.63 & -1.54 & 0.63 & -6.04 & -1.76 & 3.90 & -0.07 \\
\hline 3 & CR 15 & Uyanga & -4.84 & -0.58 & -0.69 & -0.52 & -1.52 & -2.62 & -2.07 & 4.54 & -3.71 & 0.63 & -2.24 & -4.12 & 2.07 & -0.81 \\
\hline 4 & CR 18 & Adim & -3.67 & -0.58 & -0.92 & -0.93 & 0.26 & 8.02 & -2.66 & 2.40 & -3.20 & 0.90 & -2.14 & -2.99 & 3.09 & -0.36 \\
\hline 5 & CR 19 & Ugep & -3.50 & -0.58 & -2.43 & -2.66 & -2.34 & -2.62 & -2.66 & 4.54 & -5.71 & 0.63 & -6.04 & -2.69 & 2.26 & 0.78 \\
\hline 6 & CR 23 & Obubra & -4.71 & -0.58 & -2.55 & -0.73 & -1.14 & 5.70 & -2.66 & 1.40 & -5.71 & 0.63 & -1.19 & -4.29 & 2.93 & -1.81 \\
\hline 7 & CR 23 & Okpoma & -3.94 & -0.58 & -2.69 & 0.05 & -1.87 & -2.62 & 0.19 & 0.63 & -5.04 & 0.63 & -6.04 & -5.87 & 6.56 & -5.71 \\
\hline 8 & CR 26 & Igoli-Ogoja & -4.64 & -0.58 & -2.69 & 2.05 & 2.70 & -2.62 & 3.72 & 5.84 & -3.71 & 0.63 & -6.04 & -3.91 & 7.52 & 4.86 \\
\hline 9 & CR 28 & Abakpa-Ogoja & -0.58 & -0.58 & 3.09 & -0.89 & 2.08 & -2.62 & -0.42 & 8.33 & -5.71 & 3.38 & 0.98 & -0.28 & 5.46 & 1.61 \\
\hline 10 & CR 32 & Edor & -3.43 & -0.58 & -2.69 & -2.66 & -2.72 & -2.62 & -2.66 & 0.63 & -5.71 & 0.63 & -6.04 & -2.89 & 1.77 & -0.63 \\
\hline 11 & CR 35 & Nko & -2.77 & -0.58 & -0.13 & 0.17 & 1.18 & -2.62 & -2.66 & 0.63 & -1.47 & 0.63 & -6.04 & 0.76 & 5.95 & 1.19 \\
\hline 12 & CR 38 & Obudu-Udigie & -3.75 & -0.58 & -2.69 & -1.12 & -0.72 & 3.86 & -2.66 & 0.63 & -1.67 & 0.90 & -5.49 & -1.76 & 3.17 & -5.71 \\
\hline \multirow[t]{5}{*}{13} & $\mathrm{CR} 47$ & Mbarakom & -0.56 & -0.58 & -2.69 & -2.66 & -1.29 & -2.62 & -1.39 & 1.83 & -5.71 & 0.63 & -6.04 & -0.92 & 4.09 & -1.63 \\
\hline & & Mean & -3.53 & -0.58 & -1.57 & -0.92 & -0.46 & -0.66 & -1.63 & 2.91 & -4.20 & 0.88 & -3.98 & -2.61 & 3.88 & -0.55 \\
\hline & Statistics & Minimum & -5.42 & -0.58 & -2.69 & -2.66 & -2.72 & -2.62 & -2.66 & 0.63 & -5.71 & 0.63 & -6.04 & -5.87 & 1.70 & -5.71 \\
\hline & & Maximum & -0.56 & -0.58 & 3.09 & 2.05 & 2.70 & 8.02 & 3.72 & 8.33 & -1.47 & 3.38 & 0.98 & 0.76 & 7.52 & 4.86 \\
\hline & & Std.Dev. & 1.49 & 0.00 & 1.71 & 1.32 & 1.72 & 3.82 & 1.87 & 2.60 & 1.75 & 0.76 & 2.77 & 1.80 & 1.92 & 2.86 \\
\hline
\end{tabular}

Table 6. Classification of groundwater based on index of geo-accumulation (I-geo)

\begin{tabular}{lll}
\hline Index of geo- & Designation of groundwater quality & Trace metal \\
\hline accumulation & & \\
$>5.00$ & extremely contaminated & $\mathrm{Fe}, \mathrm{Mn}, \mathrm{Sr}$ \\
$4.0-5.0$ & strongly-extremely contaminated & $\mathrm{Mn}, \mathrm{Sr}, \mathrm{Zn}$ \\
$3.0-4.0$ & strongly contaminated & $\mathrm{Co}, \mathrm{Fe}, \mathrm{Li}, \mathrm{Sr}$ \\
$2.0-3.0$ & moderately-strongly contaminated & $\mathrm{Cr}, \mathrm{Cu}, \mathrm{Mn}, \mathrm{Sr}$ \\
$1.0-2.0$ & moderately contaminated & $\mathrm{Cu}, \mathrm{Fe}, \mathrm{Mn}, \mathrm{Sr}, \mathrm{Zn}$ \\
$0.0-1.0$ & uncontaminated-moderately contaminated & $\mathrm{Cr}, \mathrm{Cu}, \mathrm{Li}, \mathrm{Mn}, \mathrm{Ni}, \mathrm{Pb}, \mathrm{Rb}, \mathrm{Sr}, \mathrm{Zn}$ \\
$<0.0$ & uncontaminated & $\mathrm{Ba}, \mathrm{Cd}, \mathrm{Cr}, \mathrm{Cu}, \mathrm{Fe}, \mathrm{Li}, \mathrm{Mo}, \mathrm{Pb}, \mathrm{Rb}, \mathrm{Sr}, \mathrm{Zn}$ \\
\hline
\end{tabular}




\subsection{Metal Load}

Metal load classification of the groundwater samples was based on the methods of references 35 and 36. The method used $\mathrm{pH}$ and the total concentration of all the metals under consideration. The total metal concentration here was computedas:

$\mathrm{Ba}+\mathrm{Cd}+\mathrm{Co}+\mathrm{Cr}+\mathrm{Cu}+\mathrm{Fe}+\mathrm{Li}+\mathrm{Mn}+\mathrm{Mo}+\mathrm{Ni}+\mathrm{Pb}+\mathrm{Rb}+\mathrm{Sr}+\mathrm{Zn}$. For the metals with contents below detectable limit, the detection value of the of the equipment for that metal was used as the concentration level as follows: These included $\mathrm{Cd}(0.1 \mu \mathrm{g} / \mathrm{l}), \mathrm{Co}(0.1 \mu \mathrm{g} / \mathrm{l}), \mathrm{Cr}(1.0 \mu \mathrm{g} / \mathrm{l}), \mathrm{Cu}(0.1 \mu \mathrm{g} / \mathrm{l}), \mathrm{Fe}$ $(1.0 \mu \mathrm{g} / \mathrm{l}), \mathrm{Li}(1.0 \mu \mathrm{g} / \mathrm{l}), \mathrm{Mn}(1.0 \mu \mathrm{g} / \mathrm{l}), \mathrm{Mo}(0.1 \mu \mathrm{g} / \mathrm{l}), \mathrm{Ni}$ $(1.0 \mu \mathrm{g} / \mathrm{l}), \mathrm{Pb}(0.1 \mu \mathrm{g} / \mathrm{l})$ and $\mathrm{Zn}(0.1 \mu \mathrm{g} / \mathrm{l})$. The data from Table 4 showed that the groundwater samples from Anantigha, Edor, Mbarakom, Nko, Obubra, Obudu, Odukpani, Okpoma, Ugep and Uyanga, which constituted $70 \%$ of all the samples, were classified as near neutral to low metal. The remaining 30\% of the samples from Abakpa, Adim, and Igoli were classified as near neutral and high metal.

\subsection{Trace Metal Pollution}

\subsubsection{Index of geoaccumulation}

The index of geoaccumulation [37] evaluation method was used to determine the level of contamination. This index required the measured value of each parameter and the given evaluation criteria (background) value. The index of geoaccumulation (1-geo) was determined as follows: Igeo $=\log 2[\mathrm{Cn} /(1.5 \times \mathrm{Bn})]$, where $\mathrm{Cn}$ is the measured concentration of element $\mathrm{n}$ in the pelitic fraction of sediment $(<2 \mu \mathrm{m})$ and $\mathrm{Bn}$ is the geochemical background for the element $\mathrm{n}$. $\mathrm{Bn}$ is either directly measured or obtained from the literature (average shale value). The factor 1.5 was introduced to include possible variations of the background values that are due to lithologic variations. In this study, the I-geo was modified for the assessment of the level of trace metal contamination in the groundwater of Cross River State. In the modification, $\mathrm{Cn}$ was the measured concentration of element $n$ in the groundwater sample and $\mathrm{Bn}$ the background concentration for the trace element $\mathrm{n}$ in groundwater obtained from the literature (Table 2).

According to the I-geo scheme, groundwater samples are classified as follows: $\mathrm{I}_{\text {geo }}<0$ uncontaminated; $0<\mathrm{I}_{\text {geo }}<1$ uncontaminated to moderately contaminated; $1<\mathrm{I}_{\text {geo }}<2$ moderately contaminated; $2<\mathrm{I}_{\text {geo }}<3$ moderately to strongly contaminated; $3<\mathrm{I}_{\text {geo }}<4$ strongly contaminated; $4<\mathrm{I}_{\text {geo }}<5$ strongly to extremely contaminated; $\mathrm{I}_{\mathrm{geo}}>5$ extremely contaminated (Mueller, 1969). The calculated index of geoaccumulation and levels of contamination by each element are listed in Tables 5 and 6 . Table 5 shows that the groundwater samples from all the sampled sites were uncontaminated with respect to barium, cadmium, chromium, copper, iron, lithium, molybdenium, lead, rubidium, strontium and zinc. However, the groundwater is extremely contaminated by iron (Adim), manganese (Anantigha, Abakpa-Ogoja) and strontium (Okpoma, IgoliOgoja, Abakpa-Ogoja, Nko). Most of the trace elements showed various degree of contamination as presented in Table 6.

\subsubsection{Enrichment Factor}

The methods of determining pollution index or enrichment factor (EF) proposed by references 38, 39 and 40 were used to assess the level of groundwater pollution in the study area. The enrichment factor was computed by averaging the ratios of the concentration to maximum admissible value (MAV) values ( $\mathrm{Ba}, \mathrm{Cd}, \mathrm{Co}, \mathrm{Cr}, \mathrm{Cu}, \mathrm{Fe}, \mathrm{Li}$, $\mathrm{Mn}, \mathrm{Mo}, \mathrm{Ni}, \mathrm{Pb}, \mathrm{Zn})$ and background value ( $\mathrm{Rb}, \mathrm{Sr})$ of all the trace elements considered as follows: $(\mathrm{Ba} / 700+\mathrm{Cd} / 5+\mathrm{Co} / 1000+\mathrm{Cr} / 50+\mathrm{Cu} / 100+\mathrm{Fe} / 300+\mathrm{L}$ $\mathrm{i} / 50+\mathrm{Mn} / 50+\mathrm{Mo} / 70+\mathrm{Ni} / 70+\mathrm{Pb} / 100+\mathrm{Rb} / 43+\mathrm{Sr} / 4.3+\mathrm{Zn} / 500$ $0) / 14$. An enrichment factor greater than 1 indicates that the element concentrations were above tolerable limits which can be from anthropogenic or natural geological sources $[41,42]$. High EF values $>2.0$ were recorded for groundwater at Abakpa-Ogoja, Igoli-Ogoja, Okpoma and Nko (Table 7). EF values in the range 1.00 - 2.0 were recorded for Adim, Obubra, Odukpani and Mbarakom, while low EF $(<1.00)$ values were recorded for five locations (Anantigha, Uyanga, Ugep, Obubra, Edor). The values of $\mathrm{EF}$ are related mainly to the levels of $\mathrm{Cr}, \mathrm{Cu}, \mathrm{Li}$ and $\mathrm{Zn}$ in groundwater. Generally, enhanced concentration of trace elements in groundwater is related to geological sources as source of contamination since the area is devoid of any major industry and characterised by low level mining activities by means of physical methods.

Table 7. Enrichment factor for different sample locations

\begin{tabular}{lll}
\hline $\mathbf{S} / \mathbf{N}$ & Name & Enrichment Factor \\
\hline 1 & Anantigha & 0.43 \\
2 & Odukpani & 1.64 \\
3 & Uyanga & 0.49 \\
4 & Adim & 1.33 \\
5 & Ugep & 0.57 \\
6 & Obubra & 0.91 \\
7 & Okpoma & 10.13 \\
8 & Igoli-Ogoja & 19.83 \\
9 & Abakpa-Ogoja & 5.21 \\
10 & Edor & 0.40 \\
11 & Nko & 6.84 \\
12 & Obudu & 1.04 \\
13 & Mbarakom & 1.98 \\
\hline
\end{tabular}




\subsection{Multivariate Analysis}

\subsubsection{Correlation}

The correlation coefficients between physicochemical parameters and trace elements and between different trace elements are reported in table 8. High correlations among elements indicated common source [43]. Barium and Co show high correlation with $\mathrm{Mg}^{2+}, \mathrm{Cl}^{-}$and $\mathrm{NO}_{3}$. Chromium, $\mathrm{Cu}, \mathrm{Li}, \mathrm{Sr}$ and $\mathrm{Zn}$ is correlated with EC/TDS, $\mathrm{pH} / \mathrm{Eh}, \mathrm{Na}^{+}$, $\mathrm{HCO}_{3}{ }^{-}$and $\mathrm{SO}_{4}{ }^{2-}$, while $\mathrm{Mn}, \mathrm{Ni}$ and $\mathrm{Pb}$ correlated with $\mathrm{Cl}^{-}$ and $\mathrm{NO}_{3}{ }^{-}$. Potassium correlated with $\mathrm{Mo}$ and $\mathrm{Rb}$, while $\mathrm{pH} / \mathrm{Eh}$ correlated with $\mathrm{Mo}$ and $\mathrm{Pb}$. Rb is highly correlated with $\mathrm{Ca}^{2+}, \mathrm{Mg}^{2+}$ and $\mathrm{Cl}^{-}$. Correlation of some trace elements ( $\mathrm{Ba}, \mathrm{Co}, \mathrm{Mn}, \mathrm{Ni}, \mathrm{Pb}$ ) with nitrate may be related to local anthropogenic activities. Barium, cobalt, manganese and nickel had high positive correlation between them: Ba-Co $(\mathrm{r}=0.65, \mathrm{p}<0.01)$, Ba-Mn $(\mathrm{r}=0.61, \mathrm{p}<0.01)$ and Ba-Ni $(\mathrm{r}=0.66, \mathrm{p}<0.01)$, which indicated same sources for these elements. Strong correlations were found for Co-Mn $(r=$ 0.97, $\mathrm{p}<0.01)$, Co-Ni $(\mathrm{r}=0.99, \mathrm{p}<0.01)$ and $\mathrm{Co}-\mathrm{Pb}(\mathrm{r}=$ $0.79, \mathrm{p}<0.01)$ and were attributed to similar sources. Chromium had strong positive correlation with $\mathrm{Cu}(\mathrm{r}=0.79$, $\mathrm{p}<0.01), \operatorname{Li}(\mathrm{r}=0.96, \mathrm{p}<0.01), \mathrm{Sr}(\mathrm{r}=0.92, \mathrm{p}<0.01)$ and $\mathrm{Zn}(\mathrm{r}=0.95, \mathrm{p}<0.01)$, which indicated common origin. Moreover, the following pairs of significant correlation were observed; $\mathrm{Li}-\mathrm{Sr}(\mathrm{r}=0.88, \mathrm{p}<0.01), \mathrm{Li}-\mathrm{Zn}(\mathrm{r}=0.99, \mathrm{p}$ $<0.01)$, Mn-Ni $(\mathrm{r}=0.97, \mathrm{p}<0.01)$ and $\mathrm{Mn}-\mathrm{Pb}(\mathrm{r}=0.83$, $\mathrm{p}$ $<0.01)$. Finally, Mo-Rb $(r=0.59, \mathrm{p}<0.01)$, Ni-Pb $(r=$ $0.76, \mathrm{p}<0.01)$ and $\mathrm{Sr}-\mathrm{Zn}(\mathrm{r}=0.85, \mathrm{p}<0.01)$. These correlations indicated several geogenic sources for these elements and limited/local anthropogenic activities.

Table 8. Pearson Correlation between physicochemical parameters and different elements

A Physicochemical parameters and trace elements

\begin{tabular}{|c|c|c|c|c|c|c|c|c|c|c|c|c|}
\hline & EC & TDS & pH & Eh & $\mathbf{N a}^{+}$ & $\mathbf{K}^{+}$ & $\mathrm{Ca}^{2+}$ & $\mathrm{Mg}^{2+}$ & $\mathrm{Cl}^{-}$ & $\mathrm{HCO}_{3}^{-}$ & $\mathrm{SO}_{4}{ }^{2-}$ & $\mathrm{NO}_{3}{ }^{-}$ \\
\hline $\mathrm{Ba}$ & 0.142 & 0.141 & -0.296 & 0.299 & -0.027 & 0.416 & 0.382 & 0.524 & 0.860 & 0.236 & -0.145 & 0.947 \\
\hline $\mathrm{Co}$ & 0.144 & 0.144 & -0.328 & 0.326 & -0.010 & 0.353 & 0.335 & 0.500 & 0.835 & 0.227 & -0.131 & 0.953 \\
\hline $\mathrm{Cr}$ & 0.941 & 0.942 & 0.706 & -0.758 & 0.971 & 0.107 & 0.067 & 0.535 & -0.018 & 0.824 & 0.981 & -0.157 \\
\hline $\mathrm{Cu}$ & 0.930 & 0.930 & 0.416 & -0.467 & 0.868 & 0.316 & 0.239 & 0.738 & 0.462 & 0.892 & 0.806 & 0.389 \\
\hline $\mathrm{Fe}$ & -0.218 & -0.218 & -0.082 & 0.092 & -0.167 & -0.187 & -0.137 & -0.255 & -0.243 & -0.285 & -0.139 & -0.266 \\
\hline $\mathrm{Li}$ & 0.915 & 0.918 & 0.546 & -0.610 & 0.993 & -0.053 & -0.121 & 0.416 & -0.087 & 0.752 & 0.995 & -0.146 \\
\hline $\mathrm{Mn}$ & 0.266 & 0.266 & -0.346 & 0.326 & 0.155 & 0.234 & 0.194 & 0.476 & 0.763 & 0.304 & 0.031 & 0.923 \\
\hline Mo & 0.117 & 0.112 & 0.647 & -0.601 & -0.055 & 0.566 & 0.713 & 0.374 & 0.185 & 0.302 & -0.011 & -0.054 \\
\hline $\mathrm{Ni}$ & 0.134 & 0.134 & -0.359 & 0.354 & 0.002 & 0.277 & 0.264 & 0.451 & 0.783 & 0.190 & -0.118 & 0.930 \\
\hline $\mathrm{Pb}$ & -0.015 & -0.014 & -0.579 & 0.564 & -0.092 & 0.092 & 0.038 & 0.198 & 0.614 & 0.065 & -0.209 & 0.809 \\
\hline $\mathrm{Rb}$ & 0.222 & 0.216 & 0.466 & -0.421 & -0.077 & 0.980 & 0.980 & 0.767 & 0.798 & 0.490 & -0.110 & 0.486 \\
\hline $\mathrm{Sr}$ & 0.993 & 0.994 & 0.697 & -0.745 & 0.968 & 0.279 & 0.215 & 0.689 & 0.198 & 0.919 & 0.956 & 0.039 \\
\hline $\mathrm{Zn}$ & 0.937 & 0.939 & 0.549 & -0.612 & 0.998 & 0.003 & -0.073 & 0.460 & -0.028 & 0.794 & 0.993 & -0.096 \\
\hline
\end{tabular}

B Trace elements

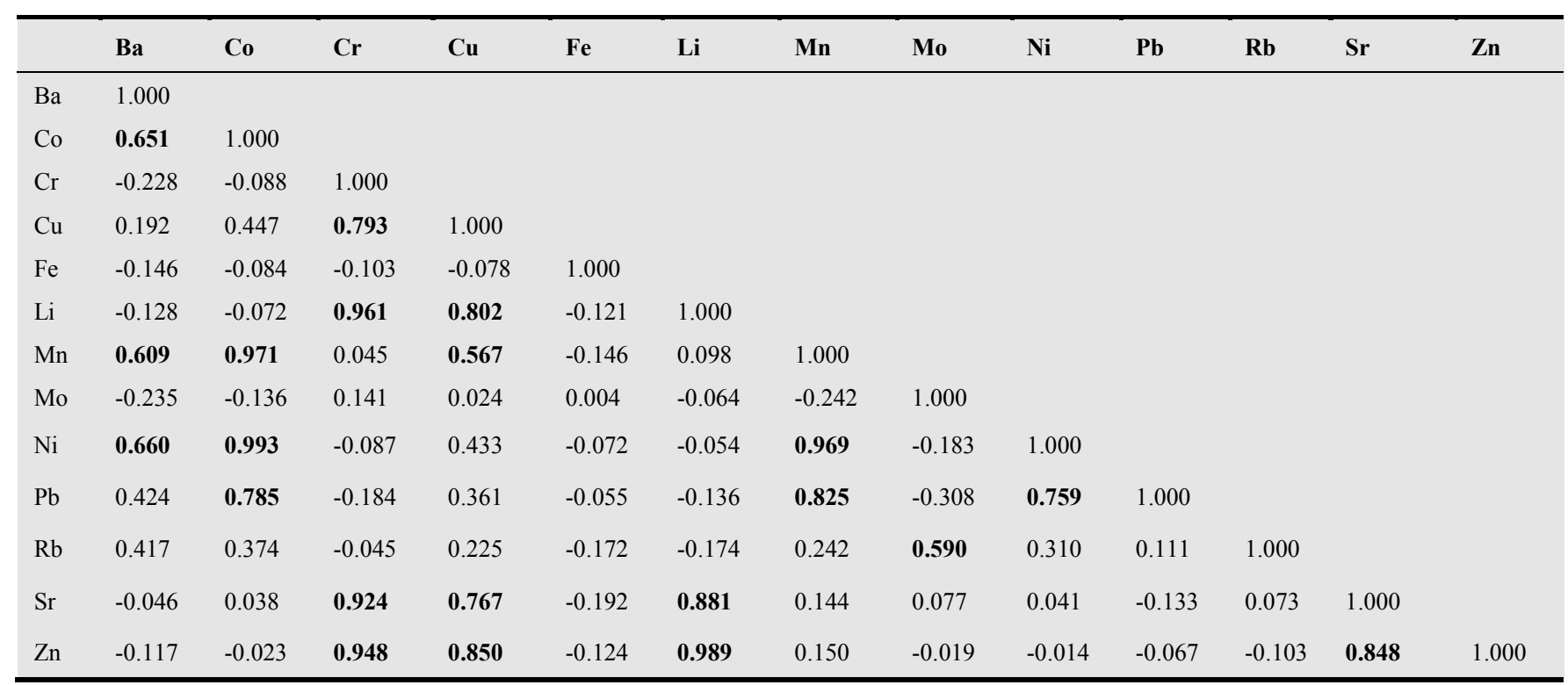

Values in bold represent significant correlation at $\mathrm{p}<0.05$. 


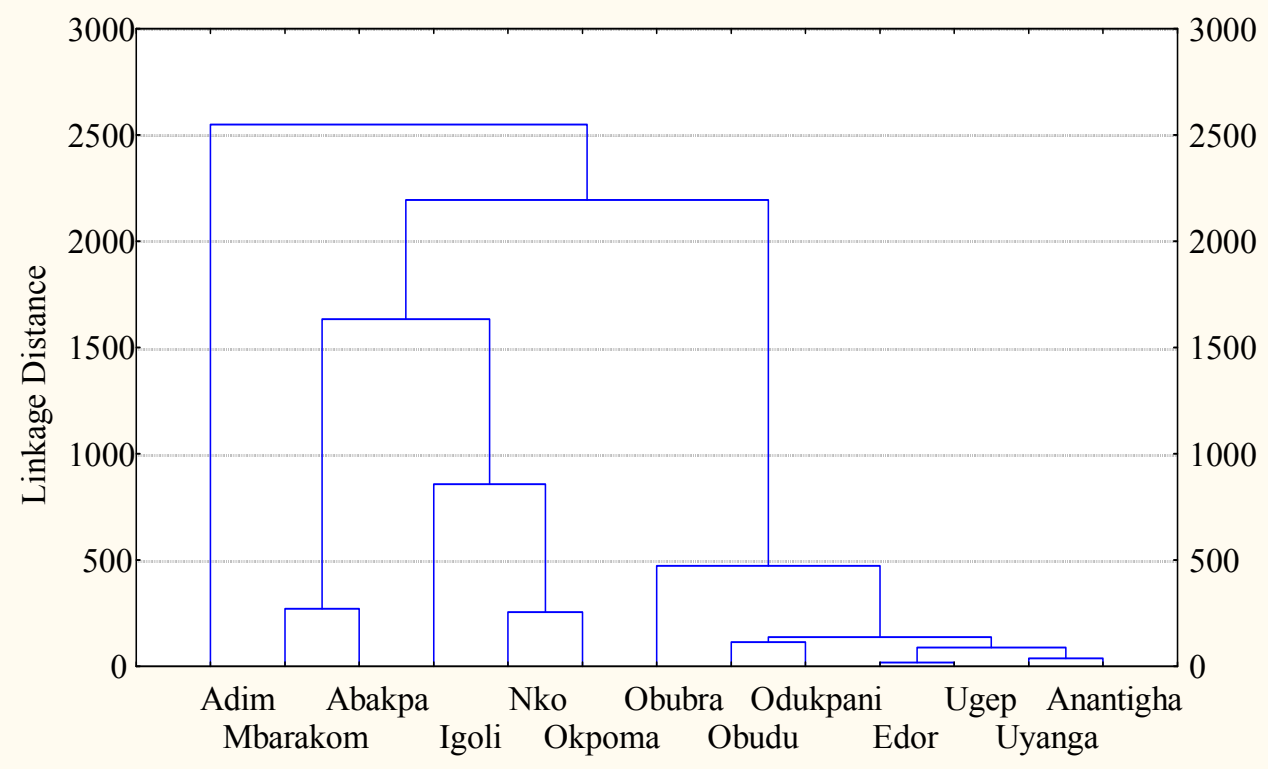

Figure 2. Dendogram of cluster analysis based on the minor and trace elements for the different sampling sites.

Table 9. Factor loading values and explained variance

\begin{tabular}{|c|c|c|c|c|}
\hline \multirow[t]{2}{*}{ Parameter } & \multicolumn{3}{|c|}{ Factor } & \multirow[b]{2}{*}{4} \\
\hline & 1 & 2 & 3 & \\
\hline Temp & 0.24 & 0.39 & -0.20 & -0.71 \\
\hline $\mathrm{EC}$ & 0.95 & 0.12 & 0.21 & 0.01 \\
\hline TDS & 0.95 & 0.12 & 0.20 & 0.01 \\
\hline $\mathrm{pH}$ & 0.59 & -0.44 & 0.64 & -0.01 \\
\hline Eh & -0.65 & 0.43 & -0.58 & 0.01 \\
\hline $\mathrm{Na}^{+}$ & 0.98 & 0.00 & -0.06 & 0.00 \\
\hline $\mathrm{K}^{+}$ & 0.10 & 0.26 & 0.91 & 0.02 \\
\hline $\mathrm{Ca}^{2+}$ & 0.03 & 0.20 & 0.96 & 0.04 \\
\hline $\mathrm{Mg}^{2+}$ & 0.54 & 0.41 & 0.69 & 0.03 \\
\hline $\mathrm{Cl}^{-}$ & 0.06 & 0.78 & 0.58 & 0.05 \\
\hline $\mathrm{HCO}_{3}^{-}$ & 0.83 & 0.19 & 0.45 & 0.09 \\
\hline $\mathrm{SO}_{4}{ }^{2-}$ & 0.97 & -0.13 & -0.05 & -0.01 \\
\hline $\mathrm{NO}_{3}^{-}$ & -0.04 & 0.93 & 0.23 & 0.11 \\
\hline $\mathrm{Ba}$ & -0.01 & 0.94 & 0.19 & -0.12 \\
\hline Co & 0.00 & 0.95 & 0.13 & -0.07 \\
\hline $\mathrm{Cr}$ & 0.96 & -0.14 & 0.07 & 0.02 \\
\hline $\mathrm{Cu}$ & 0.86 & 0.41 & 0.12 & -0.05 \\
\hline $\mathrm{Fe}$ & -0.17 & -0.17 & -0.07 & -0.84 \\
\hline $\mathrm{Li}$ & 0.97 & -0.08 & -0.13 & -0.02 \\
\hline $\mathrm{Mn}$ & 0.16 & 0.96 & -0.02 & 0.01 \\
\hline Mo & -0.02 & -0.33 & 0.79 & 0.15 \\
\hline $\mathrm{Ni}$ & 0.01 & 0.95 & 0.07 & -0.09 \\
\hline $\mathrm{Pb}$ & -0.10 & 0.85 & -0.16 & 0.15 \\
\hline $\mathrm{Rb}$ & -0.02 & 0.28 & 0.92 & 0.04 \\
\hline $\mathrm{Sr}$ & 0.96 & 0.04 & 0.18 & -0.02 \\
\hline $\mathrm{Zn}$ & 0.97 & -0.04 & -0.09 & 0.00 \\
\hline Eigen value & 10.90 & 7.33 & 4.30 & 1.25 \\
\hline$\%$ total variance & 41.91 & 28.18 & 16.54 & 4.80 \\
\hline Cumul. & 10.90 & 18.22 & 22.53 & 23.77 \\
\hline Cumul. $\%$ total variance & 41.91 & 70.10 & 86.64 & 91.44 \\
\hline
\end{tabular}

Values in bold represent marked loadings are $>.700000$

\subsubsection{Cluster Analysis}

Cluster analysis was applied to identify similar groups between the different sampling sites in the study area. The resultant dendrogram grouped the 13 sample locations into five significant clusters (Figure 2). Cluster 1 had Adim with $\mathrm{Fe}>\mathrm{Ba}>\mathrm{Sr}$; Cluster 2 consisted of Abakpa and Mbarakom having $\mathrm{Ba}>\mathrm{Sr}>\mathrm{Fe}$, while cluster 3 with $\mathrm{Sr}>\mathrm{Ba}>\mathrm{Fe}$ had Igoli, Nko and Okpoma. Cluster 4 with $\mathrm{Fe}>\mathrm{Sr}>\mathrm{Ba}$ had Obubra, Obudu, Odukpani and Anantigha. Three locations (Edor, Ugep and Uyanga) had $\mathrm{Ba}>\mathrm{Sr}>\mathrm{Fe}$, which constituted cluster 5. The concentrations of $\mathrm{Ba}, \mathrm{Sr}$, and $\mathrm{Fe}$ in cluster 5 are lower compared to the concentrations of the same elements in cluster 2. Thus generally, with low concentration of the trace elements, and with lack of major industrial or mining activity in Cross River State, the source of these elements cannot be attributed to any anthropogenic sources rather geogenic sources.

\subsubsection{Factor Analysis}

Results obtained from the application of the principal component analysis (PCA) are listed in Table 9. The PCA revealed four factors with eigenvalues greater than 1 and which explained $91.44 \%$ of the total variability of the elements were considered. EC/TDS, $\mathrm{Na}^{+}, \mathrm{HCO}_{3}^{-}, \mathrm{SO}_{4}{ }^{2-}$ chromium, copper, lithium, strontium and zinc were associated with the first factor, being the most important components and explained $41.91 \%$ of the variability. On the other hand, chloride, nitrate, barium, cobalt, manganese, nickel and lead were associated with the second factor, which represented $28.18 \%$ of the variability, while potassium, calcium, magnesium, molybdenum and rubidium were associated with the third factor, which explained $16.54 \%$ of the variability. Finally, factor four with variability of $4.80 \%$ contained only iron. As stated earlier, under cluster analysis, the low concentration of elements indicated that since the area is devoid of any 
major industrial and mining activities, the source of elements in the groundwater is mainly from weathering, minor geochemical processes including dissolution, adsorption and precipitation and local anthropogenic activities to an extent.

Factor 1 which contained EC/TDS, $\mathrm{Na}^{+}, \mathrm{HCO}_{3}{ }^{-}, \mathrm{SO}_{4}{ }^{2-}$, $\mathrm{Cr}, \mathrm{Cu}, \mathrm{Li}, \mathrm{Sr}$ and $\mathrm{Zn}$ was attributed to the dissolution of brine and to an extent to the dissolution of minerals. Dissolution of brine with high concentration of $\mathrm{Sr}$ has been reported in some parts of the study area by references 30 , 31, 32, and 33. Factor 2 had $\mathrm{Cl}^{-}, \mathrm{NO}_{3}^{-}, \mathrm{Ba}, \mathrm{Co}, \mathrm{Mn}, \mathrm{Ni}$ and $\mathrm{Pb}$. This was attributed to dissolution of barite mineral and limited anthropogenic activities. The occurrence of barite mineral had been reported in the study area by references 23, 24, 25 and 26. Factor 3 with $\mathrm{K}^{+}, \mathrm{Ca}^{2+}, \mathrm{Mg}^{2+}$, Mo and $\mathrm{Rb}$ was partly attributed to weathering of the bedrock and to an extent to dissolution of brine, while Factor 4 had only Fe and was attributed to the prevailing oxidation-reduction potential of the environment.

\section{Summary and Conclusions}

The data from this study showed that groundwater samples from Nko, Igoli and Abakpa had enhanced total dissolved solids values due to dissolution of salt beds. The $\mathrm{pH}$ of the groundwater samples showed acidic to alkaline groundwater. The concentrations of chloride, sulphate and bicarbonate were below the maximum admissible value (MAV). However, the concentration of nitrate from some locations exceeded the MAV due to poor waste management. The concentrations of sodium, calcium and magnesium in all the groundwater samples were within the permissible limit. However, potassium contents in some locations were higher than the MAV.

The trace elements considered in this study in most of the locations sampled had concentrations below MAV and typical values in fresh water. The contents of barium, iron and lead in some locations were higher than the WHO maximum admissible concentration (MAC), while the contents of cadmium, cobalt, copper, iron, manganese, nickel, lead, rubidium and zinc were within the ranges in freshwater. The concentrations of barium, chromium, lithium, molybdenum and strontium at some locations were higher than the ranges documented for freshwater. Groundwater of the study area is uncontaminated with respect to cadmium, cobalt, and copper in all locations. Most of the elements, especially Fe, Mn, $\mathrm{Sr}$ and $\mathrm{Zn}$ showed various degree of contamination. In addition, the values of enrichment factor (EF) for most elements and locations were greater than 1 . This indicated contamination from geogenic sources as the area lacks major industrial and mining activities.

Multivariate analyses showed high correlations among different elements indicated common source for these elements. Cluster analysis showed that the concentrations of three elements $(\mathrm{Fe}, \mathrm{Sr}, \mathrm{Ba})$ were responsible for the major clusters. Thus generally, with low concentration of the trace elements, and with lack of major industrial or mining activity in Cross River State, the source of these elements cannot be attributed to any anthropogenic source rather geogenic sources. The principal component analysis (PCA) revealed four factors that were attributed to dissolution of brine; dissolution of barite mineral and limited anthropogenic activities; weathering of the bedrock, and the prevailing oxidation-reduction potential of the environment, respectively for factors 1, 2, 3 and 4. In conclusion, with no major industry in the area, low concentration of elements, the groundwater in Cross River State is pristine with respect to the elements considered. Hence this study will serve as a good guide for future groundwater monitoring, pollution and management.

\section{Acknowledgement}

The first author is grateful to Alexander von Humboldt for providing fellowship to the University of Tuebingen (Germany). Prof Peter Grathwohl, my host at the University of Tuebingen and putting the facilities of the institute at my disposal. Prof Dr K-D Balke and Mr. Matthias Flegr for their hospitality during the period of this work in Tuebingen. Many thanks to Mr. Joern Breuer of Institute of Agricultural Chemistry, University of Hohenhiem, Germany for analyses of the trace elements

\section{References}

[1] Alam M, Sumbul R, Aslam M, 2012. Hydrochemical investigation and quality assessment of groundwater in rural areas of Delhi, India. Environmental Earth Sciences 66:97110

[2] Mondal N C, Singh V S, Puranik S C, Singh V P. 2010. Trace element concentration in groundwater of Pesarlanka Island, Krishna Delta, India. Environmental Monitoring Assessment 163:215-227

[3] Offiong O E, Edet A E, 1998a. Water quality assessment in Akpabuyo, Cross River basin, southeastern Nigeria. Environmental Geology 34 (2/3): 167-174.

[4] Offiong O E, Edet A E, 1998b. Surface water quality evaluation in Odukpani, Calabar Flank, southeastern Nigeria Environmental Geology 36 (3/4): 343-348.

[5] Edet A E, Offiong O E, 2002. Evaluation of water quality pollution indices for heavymetal contamination monitoring. A study case from Akpabuyo-Odukpani area, Lower Cross River Basin (southern Nigeria) Geojournal 57:295-304.

[6] Edet A E, Merkel B J, Offiong O E, 2003. Trace element hydrochemical assessment of the Calabar Coastal Plain Sands, southeastern Nigeria using statistical methods Environmental Geology 44:137-149

[7] Edet A E, Merkel B J, Offiong O E, 2004. Contamination risk assessment of a freshwater groundwater using the distribution and chemical speciation of some potentially toxic elements in Calabar (southern Nigeria).Environmental Geology 45:1025-1035. 
[8] Edet A E, Okereke C S, 2005. Hydrogeological and hydrochemical character of the regolith aquifer, northern Obudu Plateau, southern Nigeria. Hydrogeology JournalVol 13 No 2: $391-415$

[9] Edet A E, Ekpo B O, 2008. Hydrogeochemistry of a fractured aquifer in the Ogoja/Obudu area of SE Nigeria In Applied groundwater studies in Africa (EdsAdelana S, MacDonald A) IAH Selected papers on Hydrogeology, Vol 13 391-403

[10] Edet A, Nganje T N, Ukpong A J, Ekwere A S, 2011. Groundwater Chemistry and Quality of Nigeria-A status review.African Journal of Environmental Science and Technology Vol 5 (13): 1152-1169

[11] World Health Organization, WHO (1993) Guideline for drinking water quality, Geneva

[12] Edet A E, Okereke C S, Teme S C, Esu E O, 1998. Application of remote sensing data to groundwater exploration: A case study of Cross River State, southeastern Nigeria. Hydrogeology Journal 6: 394-404.

[13] Edet A E, 1993. Hydrogeology of parts of Cross River State, Nigeria: Evidence from aero-geological and surface resistivity studies. $\mathrm{PhD}$ Thesis, University of Calabar, Calabar, Nigeria $315 \mathrm{p}$

[14] Okereke C S, Esu E O, Edet A E, 1998. Determination of potential groundwater sites using geological and geophysical techniques in the Cross River State, southern Nigeria. Journal African Earth Sciences Vol 27(1): 149-163.

[15] APHA, 1980. Standard Methods for the examination of water and waste waters, $15^{\text {th }}$ edition. Washington: APHA 1980

[16] Shrestha S, Kazama F, 2007. Assessment of surface water quality using multivariate statistical techniques: a case study of Fuji river basin, Japan. Environmental Modelling and Software 22:464-475. DOI 10.1016/j.envsoft.2006.02.001

[17] Najar I A, Khan A B, 2011. Assessment of water quality and identification of pollution sources of three lakes in Kashmir, India, using multivariate analysis. Environmental Earth Sciences DOI 10.1007/s12665-011-1458-1

[18] Wu M L, Wang Y S, 2007. Using chenometrics to evaluate anthropogenic effects in Daya Bay, China. EstuarCoat Shelf Sci 72(4):732-742. DOI: 10.1016/j.ecss.2006.11.032

[19] Pilz J, 1993. Statistica for windows.StatsoftInc

[20] Parkhurst D L, 1995. PHREEQC a computer program for speciation, reaction-path, advective transport, and inverse geochemical calculations. Water resources investigation report 95-4227. Lakewood, Colorado

[21] World Health Organization, WHO (2004) Guideline for drinking water quality, Geneva

[22] World Health Organization, WHO (2008) Guideline for drinking water quality, Geneva

[23] Akpeke G B, 2000. The nature and origin of barite mineralization in Akpet Area, Oban massif, Southeastern Nigeria. M.Sc Thesis University of Calabar, Nigeria, 79p

[24] Akpeke G B, 2008. Investigation of the origin, nature and occurrence of barite mineralization in Cross River State, Southeastern Nigeria. PhD Thesis University of Calabar,
Nigeria, $178 \mathrm{p}$

[25] Adamu C I, Nganje T N, Edet A E, 2009. Hydrochemical of waters near some abandoned barite mining areas, Cross River State (SE Nigeria). In Proceedings DAAD AlumniExpert Seminar, Windhoek, Namibia, October 5-9, 2009

[26] Adamu C I, 2011. Geoenvironmental studies of Barite Mines in parts of Oban massif and Mamfe Embayment, SE Nigeria. PhD Thesis University of Calabar, Nigeria 200pp

[27] Pais I, Jones Jr J B, 1997. The Handbook of Trace Elements, St Lucie Press, Boca Raton, Florida, 223p

[28] Applin K R, Zhao N, 1989. The kinetics of Fe (II) oxidation and well screen encrustation. Groundwater 27:168-174.

[29] White A F, Benson S M, Yee A W, Woolenberg H A, Flesser S, 1991, Groundwater contamination at the Kesterson reservoir, California-Geochemical parameters influencing selenium mobility. Water Resources Research 27:1085-1098

[30] Ekwere S J, Ukpong E E, 1994. Geochemistry of saline water in Ogoja, Cross River State of Nigeria. Journal of Mining and Geology Vol 30 No 1: 11-15

[31] Tijani M N, Loehnert E P, Uma K O, 1996. Origin of saline groundwaters in the Ogoja area, Lower Benue Basin, Nigeria. Journal of African Earth Sciences 23(2): 237-252.

[32] Tijani M N, 2008. Hydrochemical and stable isotopes compositions of saline groundwaters in the Benue Basin, Nigeria. In Applied groundwater studies in Africa (EdsAdelana S, MacDonald A) IAH Selected papers on Hydrogeology, Vol 13 352-369

[33] Uma K O, 1998. The brine fields of the Benue Basin, Nigeria: a comparative study of geomorphic, tectonic and hydrochemical properties. Journal of African Earth Sciences 26(2): 261-275

[34] Coetsiers M, Blaser P, Martens K, Walraevens K, 2009. Natural background levels and threshold values for groundwater in fluvial Pleistocene and Tertiary marine aquifers in Flanders, Belgium. Environmental Geology 57:1155-1168.

[35] Ficklin W H, Plumee G S, Smith K S, McHugh J B, 1992. Geochemical classification of mine drainages and natural drainages in mineralized areas. In: Kharaka YK, Maest AS (eds), Water-Rock interaction vol 7:381-384. Balkema, Rotterdam

[36] Caboi R, Cidu R, Fanfani L, Lattanzi P, Zuddas P, 1999. Environmental mineralogy and geochemistry of abandoned $\mathrm{Pb}-\mathrm{Zn}$ Montevecchio-Ingurtosu mining district, Sardinia, Italy ChronRechMiniere 534:21-28

[37] Mueller G, 1969. Index of geoaccumulation in sediments of Rhine River, Geojournal 2 (3):108-118

[38] Buat-Menard P, Cherselet R, 1979. Variable influence of the atmospheric flux of the trace metal chemistry of oceanic suspended matter. Earth Planetery Science Letters 42:398-411

[39] Nishida H, Miyai F, Tada F, Suzuk F, 1982. Computations of index of pollution caused by heavy metals in river sediments. Environmetal Pollution Ser B 4:241-248 
[40] Krzysztof L, Wiechula D, Korns I, 2003. Metal contamination of farming soils affected by industry. Environment International 30:159-165

[41] Chon H T, Cho C H, Kim K W, Moon S H, 1996. The occurrence and dispersion of potentially toxic elements in areas covered with black shales and slates in Korea. Applied Geochemistry 11:69-76
[42] Nimick D A, Moore J M, 1991. Prediction of water soluble metal concentrations in fluvially deposited tailings sediments, Upper Clark Fork Valley, Montana, USA Applied Geochemistry 6:635-646

[43] Romic M, Romic D, 2002. Heavy metal distribution in agricultural top soils in urban areas. Environmental Geology 43:795-805. 